\title{
The Economic Value of Laem Phak Bia Mangrove Ecosystem Services in Phetchaburi Province, Thailand
}

\author{
Sitthinan Wiwatthanapornchai ${ }^{1}$, Chucheep Piputsitee ${ }^{2} \&$ Samakkee Boonyawat $^{1}$ \\ ${ }^{1}$ Faculty of Environment, Kasetsart University, Bangkok 10900, Thailand \\ ${ }^{2}$ Faculty of Economics, Kasetsart University, Bangkok 10900, Thailand \\ Correspondence: Sitthinan Wiwatthanapornchai, Faculty of Environment, Kasetsart University, Bangkok 10900, \\ Thailand. Tel: 66-825-634-888.E-mail: wiwatt_s@hotmail.com
}

\author{
Received: May 6, $2014 \quad$ Accepted: June 9, $2014 \quad$ Online Published: August 6, 2014 \\ doi:10.5539/mas.v8n5p36 URL: http://dx.doi.org/10.5539/mas.v8n5p36
}

\begin{abstract}
Thailand is a one of the nation in Southeast Asia, covered by numerous mangrove areas approximately 244,000 hectares. Phetchaburi province is the one of the province in Thailand where the mangrove area has been increasing continually since King's Royally Initiated Laem Phak Bia Environmental Research and Development Project has been set up. The mangrove ecosystems functions are vital to the livelihood of the surrounding community. Laem Phak Bia community is one that has been served from mangrove ecosystem services. This study assessed the economic value of Laem Phak Bia mangrove ecosystem services in an area approximately 237.44 hectares using Participatory Economic Valuation (PEV) by the villagers ranking and rating the importance of mangrove ecosystem services with a valuable thing for living that is the rice value. The results showed that this mangrove area was worth a total economic value about 100 million Baht per year or 424 thousand Baht per hectares per year. It could be divided into the value of regulation functions, production functions, habitat functions and information functions, which were about 38, 8, 25, and 29 million Baht per year, respectively.
\end{abstract}

Keywords: ecosystem services, participatory economic valuation, mangrove, Thailand

\section{Introduction}

Nowaday, There is approximately 244,000 hectares mangrove area in Thailand. Almost area is in the south. The value of the mangrove from ecosystem services are ecosystem functions that are directly beneficial to humans. Moreover, it is also important for the survival of aquatic plants, animals and humans. Value of the mangrove ecosystem can be classified as the direct use value, which is as a timber and non-timber usage or site for recreation, and as the indirect use value that is the role of nature such as major habitats and food source for fish or shrimp, and the value of coastal protection from wind or storm. Not only use value, mangrove forest has non-use value, which reflects the value of the satisfaction of the society for the existence of mangrove area, or heritage for descendants.

In Thailand, economic valuation of mangrove area has many case studies such as in Phang Nga Bay, in Pak Phanang, in Southern of Thailand, or in Krabi River Estuary. Almost studies assessed economic value in term of direct use, indirect use and non-use value and evaluated value by using market value or willingness to pay. The economic value of mangrove forest was estimated as a total value that could not be classified on the mangrove ecosystem functions and services (Sathirathai, 1998; Sathirathai \& Edward, 2001; Edward et al., 2002; Seenprachawong, 2002; Islam \& Ikejima, 2010; Janekarnkij, 2010).

Phetchaburi Province is the one of Thailand that the mangrove area has dramatically increased since His Majesty the King's Initiative Laem Pak Bia environmental research and development project (LERD) has been launched in 1990 and located on Laem Phak Bia Sub-district, Ban Laem District. The mangrove area has increased steadily up to 64 hectare or has an average of growth rate up to 3.71 hectares per year. (Chunkao \& Nimpee, 2012) There are four villages located nearby Laem Phak Bia mangrove area and they get the services from mangrove ecosystems.

The objectives of this study are to (1) demonstrate the role of mangrove ecosystem functions and services and (2) estimate mangrove ecosystems economic values. This value is the reflect of the importance of the mangrove 
ecosystem services for the communities. The estimated value can be used as a guideline for policy makers to make an alternative decision-making use and preserve the mangrove natural resource in term of sustainable development for the future.

\section{Method}

\subsection{Study Area}

LERD has been established since 1990 at Laem Phak Bia sub-district, Ban Laem district, Phetchaburi province with the coverage area 3.24 square kilometers. It is placed on between the latitude of $13^{\circ} 02^{\prime} 40^{\prime \prime}$ to $13^{\circ} 03^{\prime} 20^{\prime \prime} \mathrm{N}$ and longitude of $100^{\circ} 05^{\prime} 10^{\prime \prime}$ to $100^{\circ} 06^{\prime} 05^{\prime \prime} \mathrm{E}$ (UTM 1442240 to $1443480 \mathrm{~N}$ and 0619271 to $0619271 \mathrm{E}$ ). Laem Phak Bia Mangrove has area approximately 237.44 hectares as shown in Figure 1.

From secondary data collected by Department of Provincial Administration, Thailand, in Laem Phak Bia sub-district, there are four villages which are Moo 1 Ban Paneun, Moo 2 Ban Donnai, Moo 3 Ban Donklang, and Moo 4 Ban Donkadee. In 2013, the local population is 2,378 with 968 Households. Livelihood of people living in coastal villages relies mainly on fishery and laboring in the fishery and tourism business (in the short term per year) and these area villagers do not utilize neither timber nor non-timber product of mangrove forest (Table 1).

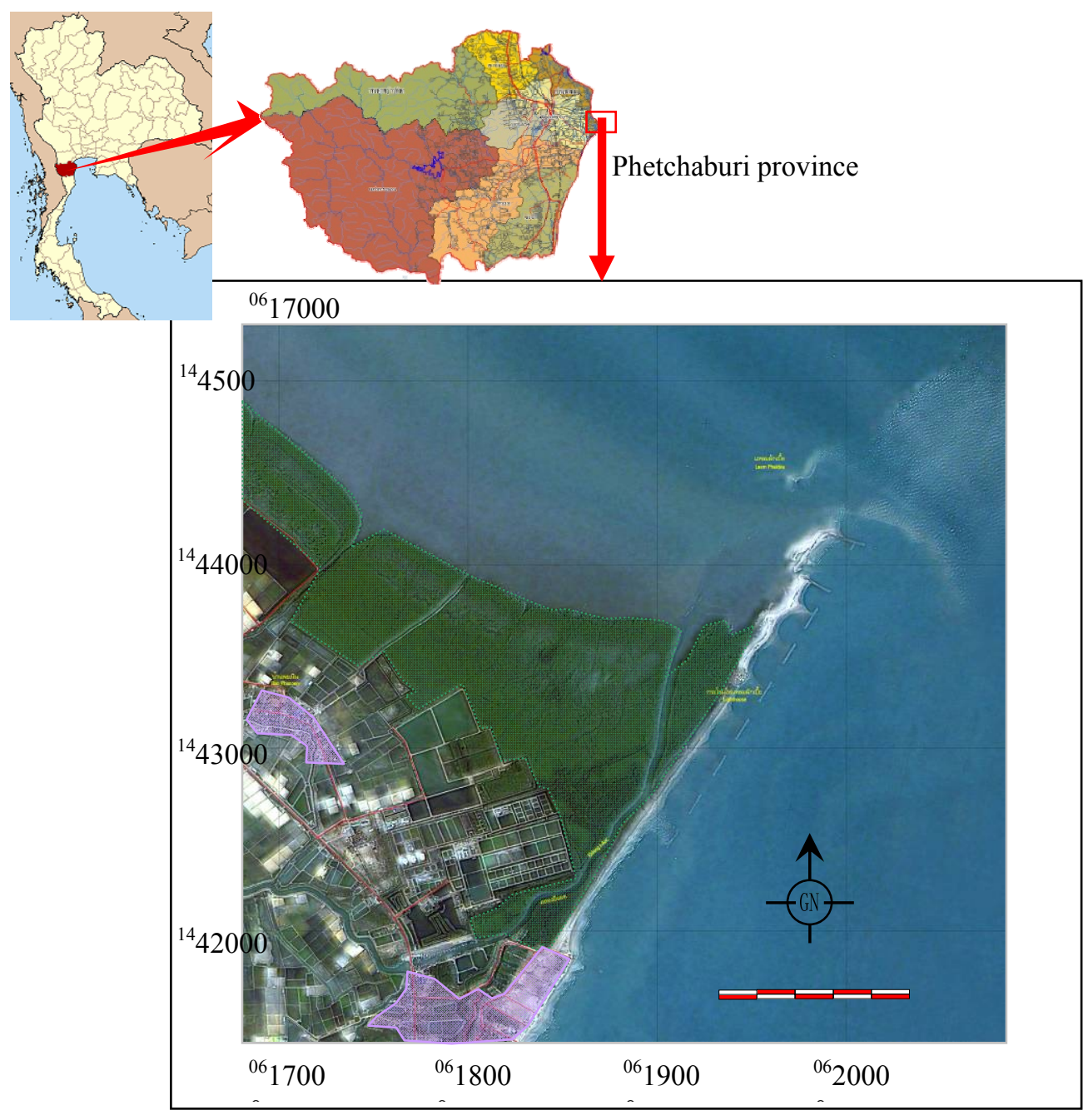

Mangrove area totally 237.44 hectare

Community area nearby Laem Pak Bia mangrove

Figure 1. Map of Laem Pak Bia Mangrove and community around mangrove area (community target) Source: Jitthaisong et al. (2012). 
Table 1. Population and number of household nearby Laem Phak Bia mangrove and resource utilization from mangrove forest in 2013

\begin{tabular}{|c|c|c|c|c|c|c|}
\hline \multirow[t]{2}{*}{ Village } & \multirow[t]{2}{*}{ Population } & \multirow{2}{*}{$\begin{array}{c}\text { No. of } \\
\text { Household }\end{array}$} & \multicolumn{4}{|c|}{ Major types of resource utilization } \\
\hline & & & $\begin{array}{c}\text { Timber / } \\
\text { Non-timber }\end{array}$ & Fishery & $\begin{array}{l}\text { Labor in } \\
\text { Fishery }\end{array}$ & Tourism \\
\hline Moo 1 Ban Paneun & 889 & 227 & $\mathrm{X}$ & $\sqrt{\sqrt{ } \sqrt{ }}$ & $\sqrt{ } \sqrt{ }$ & $\sqrt{ }$ \\
\hline Moo 2 Ban Donnai & 346 & 108 & $\mathrm{X}$ & $\sqrt{\sqrt{ }}$ & $\sqrt{ } \sqrt{ }$ & $\sqrt{ }$ \\
\hline Moo 3 Ban Donklang & 479 & 422 & $\mathrm{X}$ & $\sqrt{ } \sqrt{ }$ & $\sqrt{ } \sqrt{ }$ & $\sqrt{ }$ \\
\hline Moo 4 Ban Donkadee & 664 & 211 & $\mathrm{X}$ & $\sqrt{ } \sqrt{ }$ & $\sqrt{ } \sqrt{ }$ & $\sqrt{ }$ \\
\hline Total & 2,378 & 968 & & & & \\
\hline
\end{tabular}

Source: Department of Provincial Administration, Thailand (2013).

\subsection{Ecosystem Functions and Ecosystem Services}

Mangrove ecosystem functions are the capacity of mangrove natural processes and components to provided goods and services that satisfy human or social needs directly and indirectly (Costanza and Folke, 1997; De Groot, 1992, 1994; De Groot et al., 2002). Ecosystem functions can be grouped into four primary categories, including (1) regulation functions that relate to the capacity of natural and semi-natural ecosystem to regulate essential ecological processes and life-support systems such as gas regulation, climate regulation, waste treatment, carbon storage or nutrient regulation (2) production functions that provide many ecosystem goods and services for human consumption such as wood, food, raw material or energy resource (3) habitat functions that provide refuge and reproduction habitat to wild plants and animals and thereby contribute to the biodiversity or genetic diversity conservation and (4) information functions that provide the opportunity to maintenance human health and spirit by the scenery and landscape for human enjoyment or recreation and aesthetic experience.

Ecosystem services are the benefits provided by ecosystem to humans that contribute to making human life both possible and worth living. Leam Pak Bia mangrove has many ecosystem services include (1) provisioning services like timber and non-timber product on forest, fisheries or fresh air; (2) supporting services that are a natural process such as primary production or nutrient for plants or aquatic animals; (3) regulating services such as air and climate regulation, wastewater treatment or coastal erosion control from wind and (4) cultural services that the community can use for recreation or education.

This study evaluates mangrove ecosystem functions and ecosystem services by assessment from the important level of mangrove ecosystem functions and ecosystem services that provide to the communities. There are 5 important levels, starting from 1 which is the least important to 5 which is the most important. Then, the average of the important level was analyzed and the result was interpreted by comparing the average value with the important rank, including (1) score 5.00 - 4.21 is the most importance; (2) score 4.20 - 3.41 is the importance; (3) score $3.40-2.61$ is the moderate; (4) score $2.60-1.81$ is the less importance; and (5) score $1.80-1.00$ is the least importance.

\subsection{Mangrove Values}

Laem Phak Bia mangroves have many tangible and intangible values. In term of economic value, mangrove values are assessed from an importance of goods and services that provided to the communities. Total economic values of mangroves include use values and non use values (Figure 2). Use values or values in use is the utility of consuming a goods and services from mangroves that divided into three types which are direct use values, indirect use values and option values. Direct use values are all goods and benefits of using mangrove resources directly to produce timber and non-timber products and non commodity benefits such as recreation, education, or research in mangrove forest. Indirect use values are the environment services that value to the community such as nursery and habitat, coastal protection, wastewater treatment, or carbon storage. Option values are the current use of mangrove forest land saved for future use. Non use values or passive values are bequest values, which are the value of keeping mangrove resource intact for future generations and existence values, which are the intrinsic value of the mangrove resource (Costanza \& Folke, 1997; De Groot, 1992, 1994; De Groot et al., 2002; Pearce et al., 1992). 


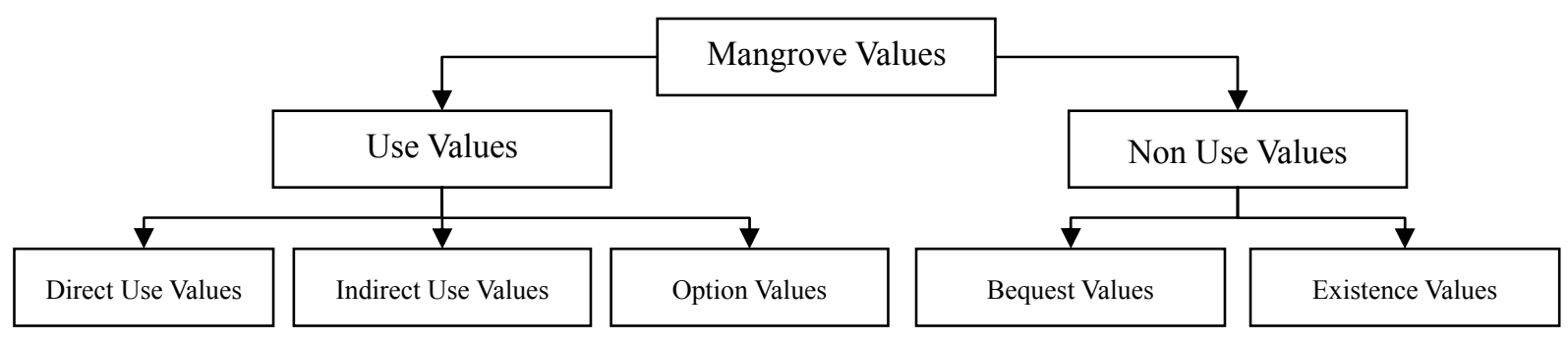

Figure 2. Classification of mangrove value

\subsection{Participatory Economic Valuation (PEV)}

Economic valuation method is a tool to allocate quantitative values to the goods and services provided from natural resources or mangrove ecosystem services (Costanza \& Folke, 1997; Daily, 1997; Daily et al., 2000; Quoc et al., 2012). Economic valuation of mangrove ecosystem services can be useful in indicating the opportunity cost of other land-use practices, and it can help in land-use decision-making. In economic valuation of natural resources, there are several methods such as market value approach, travel cost method, hedonic pricing, contingent ranking, or contingent valuation method. The best way to evaluate natural resource is the contingent valuation method that can assesses both use value and non use value via willingness to pay or willingness to accept. However, the weakness of this method is that it can not distribute value by ecosystem functions. The limitations of conventional valuation suggest that it might be a good thing to encourage active involvement of villagers in the economic valuation of their mangrove forests. However, participatory approach is a new technique in land use development in developing countries.

Participatory Environmental Valuation (PEV) is the one of the economic valuation method that uses hypothetical market. PEV is a technique to compare the value of the natural resources relies on the value of items that are valued in the market and important to survival in society (Emerton \& Mogaka, 1996; Kuchelmeister, 2003; Rosale et al., 2003; IUCN, 2005, 2006, 2007).

In the overall, Participatory Environmental Valuation (PEV) has advantages over other conventional valuation approaches which are: (1) PEV fully utilizes the data and knowledge from local decision-makers and villagers; (2) PEV maximizes the involvement and feedback of these groups; (3) PEV raises the awareness about the importance of mangrove valuation and knowledge of how to use and conserve it properly; (4) PEV can identify total value of mangrove and distribute in each ecosystem services of mangrove; (5) PEV eliminates subjective bias that make overestimate value because PEV use value of item in the communities to compare with the value of mangrove resources.

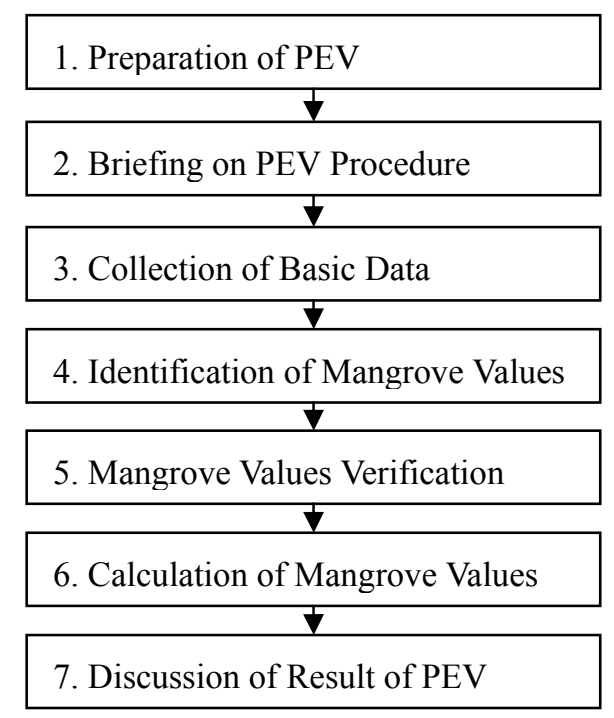

Figure 3. Participatory Economic Valuation (PEV) procedures 
Participatory Economic Valuation (PEV) has 7 steps to assess the value of mangrove ecosystem services (Figure 3). First step is to prepare of background data by collecting the secondary data in term of yield and market data in the communities. Second step is to brief the villager about the purpose, scope and the expected results of PEV and to collect the primary village data including mangrove resources utilization. Then, proceed to the next steps of PEV by collecting the primary village data and identifying mangrove values by interview key stakeholders in the communities. This step will get the first overview of the mangrove values the villagers perceive, the major direct benefits, mangrove ecosystem services, optional values, and non-use values in the village and beyond. To reconfirm the identified mangrove forest values, the sited are visited, and the physical impact area is collected in step 5. Then, step 6 is calculating the direct benefits and costs of predominant forest models in the village, subsequently also ecosystem services, optional values and non-use values. Finally in the last step, the results of the PEV exercise are discussed at a village meeting and recommendations for further actions are made by the villagers.

The calculation of the mangrove ecosystem service value performed in step 6 is the mean of proportion of importance of mangrove ecosystem service and importance of value item in the community. In this study, rice is referred to the value item that all villagers will consume it for their living, then plus with the value of rice as following equation;

$$
\text { Value of MES }=\sum_{i}\left(\text { Value of } \mathrm{MESx}_{1} \text {, Value of } \mathrm{MESx}_{2}, \ldots \ldots, \text { Value of } \mathrm{MESx}_{\mathrm{n}}\right)
$$

$$
\text { Value of } \operatorname{MESx}_{\mathrm{n}}=\operatorname{Average}\left(\frac{\mathrm{IMESx}_{\mathrm{n}_{1}}}{\mathrm{IR}_{1}} \times \mathrm{RV}_{1}, \frac{\mathrm{IMESx}_{\mathrm{n}_{2}}}{\mathrm{IR}_{2}} \times \mathrm{RV}_{2}, \ldots \ldots, \frac{\mathrm{IMESx}_{\mathrm{n}_{\mathrm{m}}}}{\mathrm{IR}_{\mathrm{m}}} \times \mathrm{RV}_{\mathrm{m}}\right)
$$

Whereas
$\begin{array}{ll}\text { Value of MES } & : \text { Value of Mangrove Ecosystem Services } \\ \text { IMESx }_{\mathrm{ij}} & \text { : Important Score of Mangrove Ecosystem Services in type } \mathrm{x}_{\mathrm{i}} \text { of person } \mathrm{j} \\ \mathrm{IR}_{\mathrm{j}} & : \text { Important Score of Rice for living of person } \mathrm{j} \\ \mathrm{RV}_{\mathrm{j}} & : \text { Value of Rice for living (Baht/Year) } \\ \mathrm{i} & : 1,2, \ldots, \mathrm{n} \\ \mathrm{j} & : 1,2, \ldots, \mathrm{m}\end{array}$

\section{Results and Discussion}

\subsection{Important rank of Leam Pak Bia Mangrove Ecosystem Services}

This study surveyed from interviewing the head of household totally 225 samples in Leam Pak Bia communities who received ecosystem services from a mangrove area. Mangroves had many ecosystem functions as shown in Table 2. The first priority was the regulation functions that were the natural role to act as a regulator in the environment. For example, mangroves could purify air pollution, as a wastewater filter from the community, and as a protective wall of wind or storm. Moreover, mangrove forest could be carbon storage in the tree and nutrient storage in the mud land. The second was the information functions; the communities received this aesthetic scene from recreation, bird watching, or ecotourism in a mangrove area. For the third function; habitat functions; communities were aware of the importance of the benthos habitat and nursery source for fish. This was due to the benthos harvest and the fishery that was the main occupation of the communities. The last was the production functions that were the direct utilization of forest resources in the mangrove area such as timber or non-timber products, the communities did not aware of the importance in these functions because mangrove area was a reserved forest area, and the communities recognized the value that they would receive ecosystem services from other ecosystem functions. 
Table 2. Important rank of Laem Phak Bia mangrove ecosystem functions and ecosystem services

\begin{tabular}{lccccc}
\hline Ecosystem Services & Moo 1 & Moo 2 & Moo 3 & Moo 4 & Total Average \\
\hline Regulation functions & & & & & \\
Purify air pollution & 4.28 & 4.09 & 3.66 & 4.03 & 4.04 \\
Wastewater treatment & 4.06 & 4.14 & 3.82 & 4.06 & 4.02 \\
Coastal protection & 4.43 & 4.17 & 3.74 & 4.00 & 4.11 \\
Nutrient Storage & 4.26 & 4.20 & 3.74 & 4.06 & 4.08 \\
Carbon Storage & 4.43 & 4.17 & 3.68 & 3.99 & 4.09 \\
$\begin{array}{l}\text { Production functions } \\
\text { Timber and fuel wood collection }\end{array}$ & 2.54 & 3.00 & 2.92 & 3.18 & 2.89 \\
Plant and herb collection & 2.31 & 3.29 & 3.12 & 3.24 & 2.92 \\
Habitat functions & & & & & \\
Nursery and food habitat of aquatic animal & 4.46 & 4.09 & 3.66 & 4.00 & 4.08 \\
Benthos habitat & 4.64 & 3.71 & 3.58 & 3.65 & 3.96 \\
Genetic diversity and biodiversity source & 4.38 & 3.94 & 3.58 & 3.71 & 3.93 \\
Information functions & & & & & \\
Natural education & 4.63 & 3.91 & 3.64 & 3.96 & 4.09 \\
Recreation & 4.54 & 3.97 & 3.70 & 3.85 & 4.06 \\
Bird watching & 4.44 & 3.89 & 3.72 & 3.87 & 4.02 \\
Nation heritage & 4.81 & 4.11 & 3.72 & 4.19 & 4.27 \\
\hline
\end{tabular}

Note. 1) score $5.00-4.21$ is the most importance.

2) score $4.20-3.41$ is the more importance.

3) score $3.40-2.61$ is the moderate importance.

4) score $2.60-1.81$ is the less importance.

5) score $1.80-1.00$ is the least importance.

\subsection{Economic Value of Leam Pak Bia Mangrove Ecosystem Services}

In this study, PEV exercise was performed in December 2013 by interviewing totally 225 samples. All villagers consumed rice as a valuable product for surviving. The average of consumed rice in the household was equal to 23.50 kilograms per month in the average price of 25 Baht per kilograms, and; therefore, the average rice value in this community was equal to 7,050 Baht per years. In the PEV exercise, the villagers were a concern on ecosystem functions and ecosystem services from the interviewer briefing. Ecosystem functions and ecosystem services were included of regulation functions, production functions, habitat functions, and information functions. Next step, the villagers, ranked the ecosystem functions and the ecosystem services from the importance that effected to himself and the communities and compared with the valuable thing, rice value, and ranked with them all. Then, all of ecosystem functions and ecosystem services and rice value were rated by villagers. This important value score would be different for each of the villagers.

Table 3 showed the average value of Laem Phak Bia mangrove ecosystem functions and ecosystem services. In overall of Laem Phak Bia communities, they focused on the occupations and the housing that shown from the important rank of ecosystem services. There was more important and the enormous value in the coastal erosion control from wind in 11.05 percentages and the benthos habitat for harvesting in 10.43 percentages. Moreover, they gave a high value in mangrove forest for the next generation in 10.88 percentages. On the other hand, the communities gave less important on production functions that shown the low percentage of timber and fuel wood, and plant and herb collection in 3.41 and 4.52 percentages, respectively.

As shown in Table 3, the PEV calculations indicated Laem Phak Bia mangrove economic value in each ecosystem functions and ecosystem services. The total value was about 10 thousand Baht per household per year or equal 100 million Baht per year and this value was based on rice value. Total economic value of mangrove could distribute value in term of ecosystem functions including;

Regulation functions; the villagers in Laem Phak Bia communities were strongly aware of the regulation functions of mangrove forest in term of coastal protection from wind and sea wave that was the first priority; the value of this function was 11,490.39 Baht per household per year. Other regulation functions were wastewater treatment, nutrient storage, purify air pollution, and carbon storage in the average value of $8,819.89,7,510.48$, 
6,093.90, and 5,773.76 Baht per household per year, respectively.

Table 3. Economic value of Laem Phak Bia mangrove ecosystem functions and ecosystem services

\begin{tabular}{|c|c|c|c|c|c|c|c|}
\hline \multicolumn{6}{|c|}{ Average Value (Baht/Household/Year) } & \multirow{2}{*}{$\begin{array}{l}\text { Total Value } \\
\text { (Million } \\
\text { Baht/Year) }\end{array}$} & \multirow{2}{*}{$\begin{array}{l}\text { Total } \\
\text { in } \%\end{array}$} \\
\hline Ecosystem services & Moo 1 & Moo 2 & Moo 3 & Moo 4 & $\begin{array}{l}\text { Total } \\
\text { Average }\end{array}$ & & \\
\hline \multicolumn{8}{|l|}{ Regulation functions } \\
\hline Purify air pollution & $7,745.39$ & $8,686.79$ & $12,868.47$ & $5,049.63$ & $6,093.90$ & 5.90 & 5.86 \\
\hline Wastewater treatment & $13,259.30$ & $12,568.43$ & $4,373.93$ & $5,459.02$ & $8,819.89$ & 8.54 & 8.48 \\
\hline Coastal protection & $13,883.44$ & $19,183.47$ & $6,576.92$ & $8,609.75$ & $11,490.39$ & 11.12 & 11.05 \\
\hline Nutrient storage & $8,662.12$ & $11,640.00$ & $5,202.18$ & $5,862.88$ & $7,510.48$ & 7.27 & 7.22 \\
\hline Carbon storage & $5,297.03$ & $14,130.54$ & $3,346.49$ & $3,761.99$ & $5,773.76$ & 5.59 & 5.55 \\
\hline Total Regulation functions & $48,847.28$ & $66,209.23$ & $32,367.99$ & $28,743.27$ & $39,688.42$ & 38.42 & 38.16 \\
\hline \multicolumn{8}{|l|}{ Production functions } \\
\hline $\begin{array}{l}\text { Timber and fuel wood } \\
\text { collection }\end{array}$ & $3,543.63$ & $7,315.40$ & $1,472.07$ & $3,129.16$ & $3,544.74$ & 3.43 & 3.41 \\
\hline Plant and herb collection & $6,323.05$ & $8,204.94$ & $9,676.67$ & $3,466.64$ & $4,704.62$ & 4.55 & 4.52 \\
\hline Total Production functions & $9,866.68$ & $15,520.34$ & $11,148.74$ & $6,595.80$ & $8,249.36$ & 7.99 & 7.93 \\
\hline \multicolumn{8}{|l|}{ Habitat functions } \\
\hline $\begin{array}{l}\text { Nursery and food habitat of } \\
\text { aquatic animal }\end{array}$ & $9,397.02$ & $11,449.71$ & $13,869.81$ & $6,170.23$ & $7,294.07$ & 7.06 & 7.01 \\
\hline Benthos habitat & $16,550.31$ & $10,599.41$ & $7,228.11$ & $7,587.11$ & $10,844.13$ & 10.50 & 10.43 \\
\hline $\begin{array}{l}\text { Genetic diversity and } \\
\text { biodiversity source }\end{array}$ & $8,116.65$ & $12,444.79$ & $4,974.40$ & $6,288.76$ & $7,539.21$ & 7.30 & 7.25 \\
\hline Total Habitat functions & $34,063.98$ & $34,493.91$ & $26,072.32$ & $20,046.10$ & $25,677.41$ & 24.86 & 24.69 \\
\hline \multicolumn{8}{|l|}{ Information functions } \\
\hline Natural education & $9,686.65$ & $17,822.82$ & $5,163.71$ & $6,033.60$ & $8,843.15$ & 8.56 & 8.50 \\
\hline Recreation & $3,926.62$ & $14,181.77$ & $1,640.05$ & $2,267.73$ & $4,512.39$ & 4.37 & 4.34 \\
\hline Bird watching & $5,373.92$ & $15,014.74$ & $3,196.04$ & $3,138.75$ & $5,714.11$ & 5.53 & 5.50 \\
\hline Nation heritage & $16,104.15$ & $16,206.51$ & $6,567.43$ & $7,227.04$ & $11,317.94$ & 10.96 & 10.88 \\
\hline Total Information functions & $35,091.34$ & $63,225.84$ & $16,567.23$ & $18,667.12$ & $30,387.59$ & 29.42 & 29.22 \\
\hline $\begin{array}{l}\text { Total Economic Value } \\
\text { (Baht/Household/Year) }\end{array}$ & $127,869.28$ & $179,449.32$ & $86,156.28$ & $74,052.29$ & $104,002.78$ & & 100.00 \\
\hline No. of Household & 227 & 108 & 422 & 211 & 968 & & \\
\hline $\begin{array}{l}\text { Total Economic Value } \\
\text { (Million Baht/Year) }\end{array}$ & 29.03 & 19.38 & 36.36 & 15.63 & 100.67 & & \\
\hline
\end{tabular}

Note. Average current rate on 2013 is 1 US dollar equal 30.73 Baht.

Production functions; this ecosystem function and ecosystem service for Laem Phak Bia communities had less value than the others because the villagers did not access to use timber and non-timber product in the mangrove forest. The value of the timber and fuel wood collection service and the plant and herb collection service of Laem Phak Bia mangrove were equal to 3,544.74 and 4,704.62 Baht per household per year, respectively.

Habitat functions; almost villagers in Laem Phak Bia communities did an offshore fishery as a main occupation, so they would give importance to habitat functions of Laem Phak Bia mangrove forest as a housing and nursery of aquatic animal. The highest value of habitat functions for this community was a benthos habitat on mud land nearly mangrove and communities that valuing 10,844.13 Baht per household per year. Habitat functions as a genetic diversity and biodiversity source and nursery and food habitat of aquatic animal had the value of 7,539.21 and 7,294.07 Baht per household per year, respectively.

Information functions; these ecosystem functions built and maintained a healthy body and mind of the human who had experience in mangroves such as a recreational or learning in natural resource or the value store for future use or next generation. The villagers in Laem Phak Bia communities had high awareness of mangrove ecosystem service for their next generation and then they gave high value for conserving Laem Phak Bia mangrove forest as a nation heritage, which valuing 11,317.94 Baht per household per year. Next, natural education from the mangrove area had the value of $8,843.15$ Baht per household per year. The value of 
recreation and bird watching in Laem Phak Bia mangrove were less than precious services, which were 4,512.39 and 5,714.11 Baht per household per year, respectively, because almost villagers did not yield from tourism in this mangrove area.

From the total economic value of Laem Phak Bia mangrove ecosystem services, when compared with the other study in Thailand, the total economic value was equal 100 million Baht per year in an area approximately 237.44 hectares or about 424 thousand Baht per hectares per year. This value was higher than the mangrove value assessed from market value approach because the value from PEV study was a sum of ecosystem services; however, and market value approach could only estimate the value of timber, non-timber, fishery, or recreation. Moreover, the value from the study using CVM or willingness to pay for assessing use and non-use value evaluated from the hypothetical market was less than the value from PEV study because the value of the CVM study depended on emotion and scenario whereas the PEV value depended on the proxy goods like the rice value. Finally, the PEV exercise could assess the total economic value in all dimensions of mangrove ecosystem functions and services.

\section{Conclusion}

It could be clearly seen that Laem Phak Bia mangrove forest had the enormous economic value in all direct use value, indirect use value and non-use value. From the PEV exercise, the results showed that a total economic value of Laem Phak Bia mangrove forest was about 100 million Baht per year. Total economic value of mangrove could be distributed in term of ecosystem functions including regulation functions, production functions, habitat functions, and information functions that were 38, 8, 25, and 29 million Baht per year, respectively. This value reflected the importance of mangrove ecosystem services for the community in term of natural protection from wind or coastal protection as a regulation function from mangrove ecosystem service. These mangroves were the housing and the nursery of benthos and aquatic animals as a habitat function. In summary, these mangroves had the high value in the indirect value. Moreover, this mangrove area also had high non-use value as a national heritage for the next generation. On the other hand, the direct use value from Laem Phak Bia mangrove forest was very low because the communities did not utilize neither timber nor non-timber product, then did not try to use as a recreation or learning, and almost villagers gave an importance for the existing mangrove forest for the future.

From the result of this study, the communities were aware of the importance of the mangrove ecosystem functions especially regulation functions, habitat functions, and information functions that are the key to the success of the operations of government agencies trying to reduce deforestation, to raise awareness and to promote reforestation of mangroves in Thailand. The policy makers should use PEV valuation method to assess the value of ecosystem functions and ecosystem services that are different in each region or locality, in order to determine the appropriate policy or guideline on the utilization and the preservation of natural resource.

\section{Acknowledgments}

This research was funded by the King's Royally Initiated Laem Phak Bia Environmental Research and Development Project, The Chaipattana Foundation.

\section{References}

Chunkao, K., \& Nimpee, C. (2012). The survey research of the rise of the coastal area nearly the King's Royally Initiated Laem Phak Bia Environmental Research and Development Project. (in Thai). The King's Royally Initiated Laem Phak Bia Environmental Research and Development Project Annual Report, The Chaipattana Foundation., Thailand.

Costanza, R., \& Folke, C. (1997). Valuing Ecosystem Services with Efficiency, Fairness and Sustainability as Goals. Washington D.C.: Island Press.

Daily, G. C. (1997). Valuing and Safeguarding Earth's Life Support Systems. Washington D.C.: Island Press.

Daily, G. C., Soderqvist, T., Aniyar, S., Arrow, K., Dasgupta, P., Ehrlich, P. R., ... Walker, B. (2000). The Value of Nature and the Nature of Value. Science, 289, 395-396. http://dx.doi.org/10.1126/science.289.5478.395

De Groot, R. S. (1992). Functions of Nature: Evaluation of Nature in Environmental Planning, Management and Decision Making. Wolters-Noordhoff, Groningen.

De Groot, R. S. (1994). Environmental functions and the economic value of natural ecosystems. Investing in Natural Capital: The Ecological Economics Approach to Sustainability. Washington D.C.: Island Press, 151-168.

De Groot, R. S., Wilson, M. A., \& Boumans, R. M. J. (2002). A Typology for the Classification, Description and 
Valuation of Ecosystem Functions, Goods and Services. Ecological Economic, 41, 393-408. http://dx.doi.org/10.1016/S0921-8009(02)00089-7

Department of Provincial Administration. (2013). Population and number of household in Laem Phak Bia sub-district, Ban Laem district, Phetchaburi province. Department of Provincial Administration, Thailand.

Edward, B. B., Strand, I., \& Sathirathai, S. (2002). Do Open Access Conditions Affect the Valuation of an Externality? Estimating the Welfare Effects of Mangrove-Fishery Linkages. Environmental and Resource Economics, 21(4), 343-367. http://dx.doi.org/10.1023/A:1015129502284

Emerton, L., \& Mogaka, H. (1996). Participatory Environmental Valuation of Forest Resources in the Aberdares, Kenya. PLA Notes. London, 6-10.

Islam, M. S., \& Ikejima, K. (2010). Gear type, species composition and economic value of fisheries in the mangroves of Pak Phanang, Thailand. Wetlands Ecology and Management, 18(1), 27-36. http://dx.doi.org/10.1007/s11273-009-9145-7

IUCN. (2005). Balancing the Returns to Catchment Management: The Economic Value of Conserving Natural Forests in Sekong, Lao PDR. A Report to the World Conservation Union, Centre for Social and Economic Research on the Global Environment.

IUCN. (2006). Valuation, Rehabilitation and Conservation of Mangroves in Tsunami Affected Areas of Hambantota, Sri Lanka. A Report to the World Conservation Union, Centre for Social and Economic Research on the Global Environment.

IUCN. (2007). Environmental and Socio Economic Value of Mangroves in Tsunami Affected Areas: Rapid Mangrove Valuation Study, Panama Village in South Eastern Coast of Sri Lanka. A Report to the World Conservation Union, Centre for Social and Economic Research on the Global Environment.

Janekarnkij, P. (2010). Assessing the Value of Krabi River Estuary Ramsar Site Conservation and Development. ARE Working Paper No. 2553/4 (December 2010).

Jitthaisong, O., Dhanmanonda, P., Chunkao, K., \& Teejuntuk, S. (2012). Water quality from Mangrove forest: The King's royally initiated Laem Phak Bia Environmental Research and Development Project: Phetchaburi Province, Thailand. Modern Applied Science, 6(8), 1-8. http://dx.doi.org/10.5539/mas.v6n8p1

Kuchelmeister, G. (2003). Participatory Economic Evaluation - Experience in Forest Valuation with Villagers in Vietnam. Paper Present for the Frontiers 2 Conference: European Applications in Ecological Economics 12-15 February 2003, Tenerife, Canary Islands, Spain.

Pearce, D. W., Moran, D., \& Fripp, E. (1992). The Economic Value of Biological and Cultural Diversity. A Report to the World Conservation Union, Centre for Social and Economic Research on the Global Environment.

Quoc, T. V., Kuenzer, C., Quang, M. V., Moder, F., \& Oppelt, N. (2012). Review of valuation methods for mangrove ecosystem services. Ecological Indicators, 23, 431-446. http://dx.doi.org/10.1016/j.ecolind.2012.04.022

Rosales, R., Kallesoe, M., Gerrard, P., Muangchanh, P., Phomtavong, S., \& Khamsomphou, S. (2003). The Economic Returns from Conserving Natural Forests in Sekong, Lao PDR. IUCN / The World Conservation Union Asia Regional Environmental Economics Programme and WWF Lao Country Office, Vientiane.

Sathirathai, S. (1998). Economic Valuation of Mangroves and the Roles of Local Communities in the Conservation of Natural Resources: Case Study of Surat Thani, South of Thailand. Economy and Environment Program for Southeast Asia. (EEPSEA), Research Report.

Sathirathai, S., \& Edward, B. B. (2001). Valuing Mangrove Conservation in Sounthern Thailand. Contemporary Economic Policy, 19(2), 109-122. http://dx.doi.org/10.1111/j.1465-7287.2001.tb00054.x

Seenprachawong, U. (2002). An Economic Valuation of Coastal Ecosystems in Phang Nga Bay, Thailand. EEPSEA Research Report Series No. 2002-RR5. Singapore: IDRC.

\section{Copyrights}

Copyright for this article is retained by the author(s), with first publication rights granted to the journal.

This is an open-access article distributed under the terms and conditions of the Creative Commons Attribution license (http://creativecommons.org/licenses/by/3.0/). 